\title{
Hubungan status gingiva dengan kebiasaan menyirih pada masyarakat di Kecamatan Manganitu
}

\author{
${ }^{1}$ Cheny Hontong \\ ${ }^{2}$ Christy N. Mintjelungan \\ ${ }^{2}$ Kustina Zuliari \\ ${ }^{1}$ Kandidat Skripsi Program Studi Pendidikan Dokter Gigi Fakultas Kedokteran \\ ${ }^{2}$ Program Studi Pendidikan Dokter Gigi Fakultas Kedokteran \\ Universitas Sam Ratulangi Manado \\ Email: chennyhontong@yahoo.com
}

\begin{abstract}
Oral health is very important for every individual. Gingivitis is an inflammation of the gingiva caused by the interaction of microorganisms in plaques and bad habits inter alia the habit of chewing betel. This study was aimed to determine the relationship of gingival status and chewing habits based on the duration of betel chewing and chewing frequencies per day among Manganitu district community. This was a descriptive-analytical study with a cross-sectional design. Samples were taken by using purposive sampling. There were 39 respondents as samples. Clinical data of the gingival status was measured by using gingival index (GI) of Loe and Sillnes. The results of chi-square analysis showed a significant correlation between the gingival status and the betel chewing habit based on the duration of betel chewing habit $(\mathrm{p}=0.000)$ and the frequency of betel chewing per day $(\mathrm{p}=0.001)$. Conclusion: Gingival status of Manganitu district community who had betel chewing habit was classified in the severe category.
\end{abstract}

Keywords: Status gingiva, chewing habits, Manganitu districts.

\begin{abstract}
Abstrak: Kesehatan gigi dan mulut sangat penting bagi setiap individu. Gingivitis merupakan inflamasi pada gingiva yang disebabkan oleh interaksi mikroorganisme pada plak dan kebiasaan buruk, salah satunya ialah kebiasaan menyirih. Penelitian ini bertujuan untuk mengetahui hubungan status gingiva dengan kebiasaan menyirih berdasarkan lama menyirih dan frekuensi menyirih perhari pada masyarakat kecamatan Manganitu. Jenis penelitian ialah deskriptif-analitik dengan desain potong lintang. Sampel diperoleh dengan metode purposive sampling sebanyak 39 responden. Data klinis tentang status gingiva diukur menggunakan gingival index (GI) menurut Loe dan Sillnes. Berdasarkan hasil uji analisis chi-square terdapat hubungan bermakna antara status gingiva dengan kebiasaan menyirih berdasarkan lama menyirih $(\mathrm{p}=0,000)$ dan frekuensi menyirih $(\mathrm{p}=0,001)$. Simpulan: Status gingiva masyarakat kecamatan Manganitu yang memiliki kebiasaan menyirih tergolong dalam kategori berat.
\end{abstract}

Kata kunci: status gingiva, kebiasaan menyirih

Kesehatan gigi dan mulut sangat penting bagi kesehatan setiap individu. Kesehatan gigi dan mulut yang bermasalah atau tidak sehat dapat mengganggu fungsi bicara, pengunyahan, serta fungsi estetik yang dapat berdampak pada aktivitas seseorang. Berdasarkan Federation Dentaire International (FDI) sekitar 90\% penduduk dunia berisiko mengalami penyakit gigi dan mulut, mulai dari karies gigi, penyakit periodontal hingga kanker mulut. Data terbaru WHO Oral Health Media Center 2012 memperlihatkan sebanyak 60\%-90\% anak usia sekolah bahkan orang dewasa diseluruh dunia memiliki masalah kesehatan gigi dan mulut. Hasil laporan 
Riset Kesehatan Dasar (RISKESDAS) 2013 Provinsi Sulawesi Utara menyatakan bahwa terdapat sebesar $31,6 \%$ masalah kesehatan gigi dan mulut termasuk gingiva. ${ }^{1}$

Gingiva merupakan jaringan lunak yang mengelilingi akar gigi dan melekat pada tulang alaveolar. Inflamasi atau peradangan pada gingiva disebut dengan gingivitis. Di Indonesia gingivitis menduduki urutan kedua yaitu mencapai $96,58 \% .^{2.3}$ Gingivitis merupakan salah satu penyakit periodontal yang disebabkan adanya interaksi mikroorganisme pada plak, serta sel-sel inflamasi pada jaringan. Penyebab lain yang menunjang terjadinya gingivitis yaitu overhanging, debris makanan, susunan gigi kurang baik, traumatik oklusi, dan kebiasaan buruk. ${ }^{4.5}$ Kebiasaan buruk yang dilakukan masyarakat erat kaitannya dengan terjadinya gangguan pada gingiva yang dipengaruhi oleh faktor perilaku masyarakat. ${ }^{6}$ Perilaku masyarakat seringkali dipengaruhi oleh kebudayaan atau kebiasaan yang berlaku dalam masyarakat itu sendiri. Salah satu faktor kebudayaan yang ditemui dalam masyarakat yaitu kebiasaan menyirih.

Menyirih merupakan kegiatan yang telah bersifat turun-temurun yang berhubungan dengan upacara dan kegiatan budaya serta sosial. Kebiasaan menyirih ini telah dimulai sejak 2000 tahun yang lalu di daerah Asia Selatan, Asia Tenggara dan Pasifik Selatan. $^{7} \quad$ Kebiasaan menyirih merupakan proses meramu yaitu campuran dari beberapa komponen seperti pinang, sirih, kapur, dan beberapa komponen lainnya yang dikunyah dalam waktu beberapa menit. Kebiasaan menyirih memiliki dampak positif dan negatif. Dampak positif menyirih ialah dapat menghambat proses pembentukan karies pada gigi, sedangkan dampak negatifnya ialah timbulnya stein pada gigi dan dapat menyebabkan terjadinya gingivitis. ${ }^{5,6,8}$

Hasil penelitian yang dilakukan $\mathrm{Ni}$ Wayan Arini (2012) pada orang yang menyirih di Banjar Sedana Merttha Kota Denpasar melaporkan bahwa terdapat hubungan bermakna antara menyirih dengan keadaan jaringan periodontal. Kebiasaan menyirih masih dilakukan oleh masyarakat Kecamatan Manganitu hingga saat ini. Penelitian ini bertujuan untuk mengetahui hubungan status gingiva dengan kebiasaan menyirih pada masyarakat di Kecamatan Manganitu.

\section{BAHAN DAN METODE PENELITIAN}

Jenis penelitian ini ialah deskriptifanalitik dengan desain potong lintang. Penelitian ini dilakukan di Kabupaten Kepulauan Sangihe Kecamatan Manganitu, pada bulan Juli 2016. Populasi penelitian ialah masyarakat berusia 40-89 tahun yang memiliki kebiasaan menyirih di Kecamatan Manganitu yang berjumlah 66 responden. Besar sampel yang memenuhi kriteria inklusi berjumlah 39 responden yang diperoleh menggunakan teknik purposive sampling.

Kriteria inklusi yaitu bersedia untuk mengikuti penelitian dan menandatangani informed consent, bersikap kooperatif, hadir saat penelitian, tidak memiliki penyakit sistemik, memiliki kebiasaan menyirih minimal selama 1 tahun. Kriteria eksklusi yaitu memiliki kebiasaan merokok, dan tidak memiliki gigi indeks.

Alat dan bahan dalam penelitian ini yaitu lembar pemeriksaan, kaca mulut, masker, sarung tangan, probe periodontal (WHO), nier beken, kapas, alkohol 70\%, air kumur (kemasan), air bersih untuk membersihkan alat, kain putih ukuran kecil.

Status gingival adalah keadaan yang menggambarkan kondisi kesehatan gingiva, dimana gingiva dalam keadaan normal maupun terinflamasi. Pengukuran yang digunakan dalam penelitian ini menggunakan indeks gingiva menurut Loe dan Sillnes yaitu keempat area gingiva pada masing-masing gigi (fasial, mesial, distal, dan lingual) dinilai tingkat paradangannya dan diberi skor 0-3. Untuk mempermudah pengukuran dapat digunakan enam gigi terpilih sebagai indeks yaitu molar pertama kanan atas, insisif kanan atas, premolar pertama kiri atas, molar pertama kiri bawah, insisif pertama kanan bawah, dan premolar pertama kanan bawah. Gigi-gigi 
indeks tersebut dikenal dengan nama Ramfjord teeth. ${ }^{9}$

Kebiasaan menyirih adalah kebiasaan yang dilakukan masyarakat dalam proses meramu terdiri dari beberapa komponen seperti sirih, pinang, dan kapur yang dikunyah dalam waktu beberapa menit. Lama menyirih ialah lamanya responden melakukan kebiasaan menyirih yang dimulai sejak pertama kali sampai penelitian ini dilakukan di Kecamatan Manganitu, yang dibagi atas tiga kategori yaitu: $<5$ tahun, 5-10 tahun, dan $>10$ tahun. Frekuensi menyirih ialah jumlah menyirih dalam sehari, dibagi atas tiga kategori yaitu: <3 kali, 3-5 kali, dan >5 kali.

Pengambilan data yaitu data klinik mengenai indeks gingiva diperoleh dengan melakukan pemeriksaan langsung di dalam rongga mulut dengan bantuan kaca mulut. Sebelum diperiksa, pasien diberikan segelas air mineral untuk berkumur. Pemeriksaan dilakukan sesuai prinsip gingiva indeks (GI).

Hasil pemeriksan dicatat pada lembar pemeriksaan. Pengambilan data dilakukan dengan cara mendatangi subjek di tiap-tiap desa. Data demografi berupa usia, jenis kelamin, dan kebiasaan menyirih dilakukan melalui wawancara langsung dan dengan menggunakan formulir pemeriksaan.

Pengolahan data menggunakan analisis univariat dalam bentuk distribusi frekuensi dan persentase, sedangkan untuk melihat hubungan kebiasaan menyirih berdasarkan lama menyirih dan frekuensi menyirih perhari dengan status gingiva secara bivariat dilakukan dengan uji Chi-square.

\section{HASIL PENELITIAN}

Kecamatan Manganitu terletak di bagian Selatan dari ibukota Kabupaten Kepulauan Sangihe. Jumlah penduduk kecamatan Manganitu laki-laki 4.631 jiwa dan perempuan 7.813 jiwa total 12.444 jiwa. Jumlah desa yang ada di kecamatan tersebut berjumlah 18 desa dan yang menjadi pusat penelitian hanya 8 desa yakni desa Manumpitaeng, Hiung, Tawoali, Bengka, Nahepese, Barangka, Taloarane 1 dan Taloarane induk.
Jumlah responden berjenis kelamin laki-laki sebanyak 25 orang $(64,1 \%)$, dan jumlah responden perempuan sebanyak 14 orang $(35,9 \%)$ (Tabel 1).

Tabel 1. Karakteristik responden berdasarkan jenis kelamin

\begin{tabular}{ccc}
\hline $\begin{array}{c}\text { Jenis } \\
\text { kelamin }\end{array}$ & $\begin{array}{c}\text { Jumlah } \\
(\mathbf{n})\end{array}$ & $\begin{array}{c}\text { Persentase } \\
(\boldsymbol{\%})\end{array}$ \\
\hline Laki-laki & 25 & 64,1 \\
Perempuan & 14 & 35,9 \\
Total & 39 & 100 \\
\hline
\end{tabular}

Hasil penelitian mendapatkan jumlah responden terbanyak yang berusia 50-59 tahun sebanyak 11 orang $(28,2 \%)$ (Tabel 2).

Tabel 2. Karakteristik responden berdasarkan usia

\begin{tabular}{ccc}
\hline $\begin{array}{c}\text { Usia } \\
\text { (tahun) }\end{array}$ & $\begin{array}{c}\text { Jumlah } \\
(\mathbf{n})\end{array}$ & $\begin{array}{c}\text { Persentase } \\
(\boldsymbol{\%})\end{array}$ \\
\hline $40-49$ & 9 & 23,1 \\
$50-59$ & 11 & 28,2 \\
$60-69$ & 9 & 23,1 \\
$70-79$ & 7 & 17,9 \\
$80-89$ & 3 & 7,7 \\
Total & 39 & 100 \\
\hline
\end{tabular}

Hasil penelitian mendapatkan responden yang mempunyai status gingiva berat sebanyak 17 orang $(43,6 \%)$, status gingiva sedang sebanyak 13 orang $(33,3 \%)$, dan status gingiva ringan sebanyak 9 orang $(23,1 \%)$ (Tabel 3).

Tabel 3. Distribusi responden berdasarkan status gingiva

\begin{tabular}{ccc}
\hline $\begin{array}{c}\text { Status } \\
\text { gingiva }\end{array}$ & $\begin{array}{c}\text { Jumlah } \\
(\mathbf{n})\end{array}$ & $\begin{array}{c}\text { Persentase } \\
(\boldsymbol{\%})\end{array}$ \\
\hline Ringan & 9 & 23,1 \\
Sedang & 13 & 33,3 \\
Berat & 17 & 43,6 \\
Total & 39 & 100 \\
\hline
\end{tabular}

Hasil penelitian memperlihatkan bahwa yang memiliki kebiasaan menyirih lebih dari 10 tahun sebanyak 15 responden $(38,5 \%), \quad 5-10$ tahun sebanyak 19 responden $(48,7 \%)$, dan $<5$ tahun sebanyak 
5 responden $(12,8 \%)$ (Tabel 4).

Tabel 4. Distribusi responden berdasarkan lama menyirih (tahun)

\begin{tabular}{ccc}
\hline $\begin{array}{c}\text { Lama } \\
\text { menyirih } \\
\text { (tahun) }\end{array}$ & $\begin{array}{c}\text { Jumlah } \\
(\mathbf{n})\end{array}$ & $\begin{array}{c}\text { Persentase } \\
(\boldsymbol{\%})\end{array}$ \\
\hline$<5$ & 5 & 12,8 \\
$5-10$ & 19 & 48,7 \\
$>10$ & 15 & 38,5 \\
Total & 39 & 100 \\
\hline
\end{tabular}

Hasil penelitian mendapatkan yang memiliki kebiasaan menyirih lebih dari 5 kali dalam sehari sebanyak 4 responden $(10,3 \%), 3$ hingga 5 kali sebanyak 24 responden $(61,5 \%)$, dan kurang dari 3 kali sehari sebanyak 11 responden $(28,2 \%)$ (Tabel 5).

Tabel 5. Distribusi responden berdasarkan frekuensi menyirih perhari

\begin{tabular}{ccc}
\hline $\begin{array}{c}\text { Frekuensi } \\
\text { (perhari) }\end{array}$ & $\begin{array}{c}\text { Jumlah } \\
(\mathbf{n})\end{array}$ & $\begin{array}{c}\text { Persentase } \\
(\%)\end{array}$ \\
\hline$<3$ & 11 & 28,2 \\
$3-5$ & 24 & 61,5 \\
$>5$ & 4 & 10,3 \\
Total & 39 & 100 \\
\hline
\end{tabular}

Analisis hubungan status gingiva dengan kebiasaan menyirih menggunakan analisis bivariat dengan uji Chi-square.

\section{Analisis hubungan status gingiva dan lama menyirih}

Responden yang memiliki kebiasaan menyirih lebih dari 10 tahun memiliki status gingiva yang berat 15 responden $(38,5 \%)$, sedang sebanyak $(0 \%)$, dan ringan sebanyak $(0 \%)$. Responden yang menyirih 5-10 tahun memiliki status gingiva berat sebanyak 2 responden $(5,1 \%)$, sedang sebanyak 11 responden $(28,2 \%)$, dan ringan sebanyak 6 responden $(15,4 \%)$. Responden yang menyirih $<5$ tahun memiliki status gingiva berat sebanyak $(0 \%)$, sedang sebanyak 2 responden $(5,1 \%)$, dan ringan sebanyak 3 responden $(7,7 \%)$. Berdasarkan analisis dengan Chi-square diperoleh hasil $\mathrm{p}=0,000 \quad(\mathrm{p}<0,005)$ yang artinya terdapat hubungan bermakna antara lama menyirih dengan status gingival (Tabel 6).

\section{Analisis hubungan status gingiva dan} frekuensi menyirih per hari.

Responden yang memiliki frekuensi menyirih $>5$ kali dalam sehari memiliki status gingiva berat sebanyak 4 responden $(10,3 \%)$, sedang sebanyak (0\%), dan ringan sebanyak $(0 \%)$. Yang memiliki frekuensi menyirih 3-5 kali dalam sehari memiliki status gingiva berat sebanyak 12 responden $(30,8 \%)$, sedang sebanyak 10 responden $(25,6 \%)$, dan ringan sebanyak 2 responden $(5,1 \%)$. Yang memiliki frekuensi menyirih $<3$ kali dalam sehari memiliki status gingiva berat sebanyak 1 responden $(2,6 \%)$, sedang sebanyak 3 responden $(7,7 \%)$, dan ringan sebanyak 7 responden $(17,9 \%)$. Berdasarkan analisis dengan Chi-square diperoleh hasil $\mathrm{p}=0,001 \quad(\mathrm{p}<0,005)$ yang artinya terdapat hubungan bermakna antara frekuensi menyirih dalam sehari dengan status gingival (Tabel 7).

\section{BAHASAN \\ Distribusi status gingiva}

Penelitian status gingiva dikategorikan dalam 3 kelompok yaitu: berat, sedang, dan ringan. Tabel 3 menunjukkan bahwa keadaan status gingiva pada masyarakat Kecamatan Manganitu yang memilki kebiasaan menyirih terbanyak termasuk kategori berat sebanyak 17 responden $(43,6 \%$.). Hal ini sejalan dengan penelitian oleh Welmince et al. dan Gabriella et al. yang juga meneliti kebiasaan menyirih dan melaporkan bahwa terdapat hubungan bermakna antara kebiasaan menyirih dengan terjadinya penyakit periodontal, salah satunya gingivitis. Hal tersebut terjadi disebabkan karena kebersihan mulut atau Oral Hygiene (OHI-S) yang tidak dijaga atau dibersihkan dari sisa-sisa bahan menyirih, sehingga mengakibatkan bertumpuknya kalkulus dan terjadi iritasi terus-menerus seiring dengan bertambah lamanya waktu menyirih dilakukan. ${ }^{5,6,9,10}$ 
Tabel 6. Hubungan status gingiva dan lama menyirih

\begin{tabular}{|c|c|c|c|c|c|c|c|c|c|}
\hline \multirow{3}{*}{$\begin{array}{c}\text { Lama } \\
\text { menyirih } \\
\text { (tahun) }\end{array}$} & \multicolumn{6}{|c|}{ Status gingiva } & \multirow{2}{*}{\multicolumn{2}{|c|}{ Total }} & \multirow{3}{*}{$p$-value } \\
\hline & \multicolumn{2}{|c|}{ Ringan } & \multicolumn{2}{|c|}{ Sedang } & \multicolumn{2}{|c|}{ Berat } & & & \\
\hline & $\mathrm{n}$ & $(\%)$ & $\mathrm{n}$ & $(\%)$ & $\mathrm{n}$ & $(\%)$ & $\mathrm{n}$ & $(\%)$ & \\
\hline$<5$ & 3 & 7,7 & 2 & 5,1 & 0 & 0 & 5 & 12,8 & \\
\hline $5-10$ & 6 & 15,4 & 11 & 28,2 & 2 & 5,1 & 19 & 48,7 & $0,000 *$ \\
\hline$>10$ & 0 & 0 & 0 & 0 & 15 & 38,5 & 15 & 38,5 & \\
\hline Total & 9 & 23,1 & 13 & 33,3 & 17 & 43,6 & 39 & 100 & \\
\hline
\end{tabular}

Tabel 7. Hubungan status gingiva dan frekuensi menyirih

\begin{tabular}{|c|c|c|c|c|c|c|c|c|c|}
\hline \multirow{3}{*}{$\begin{array}{l}\text { Frekuensi } \\
\text { (perhari) }\end{array}$} & \multicolumn{6}{|c|}{ Status gingival } & \multirow{2}{*}{\multicolumn{2}{|c|}{ Total }} & \multirow{3}{*}{$p$-value } \\
\hline & \multicolumn{2}{|c|}{ Ringan } & \multicolumn{2}{|c|}{ Sedang } & \multicolumn{2}{|c|}{ Berat } & & & \\
\hline & $\mathrm{n}$ & $(\%)$ & $\mathrm{n}$ & $(\%)$ & $\mathrm{n}$ & $(\%)$ & $\mathrm{n}$ & $(\%)$ & \\
\hline$<3$ kali & 7 & 17,9 & 3 & 7,7 & 1 & 2,6 & 11 & 28,2 & \\
\hline 3-5 kali & 2 & 5,1 & 10 & 25,6 & 12 & 30,8 & 24 & 61,5 & $0,001 *$ \\
\hline$>5$ kali & 0 & 0 & 0 & 0 & 4 & 10,3 & 4 & 10,3 & \\
\hline Total & 9 & 23,1 & 13 & 33,3 & 17 & 43,6 & 39 & 100 & \\
\hline
\end{tabular}

Tabel 1 memperlihatkan kebiasaan menyirih paling banyak dilakukan oleh responden laki-laki sebanyak 25 orang $(64,1 \%)$ sedangkan responden perempuan sebanyak 14 orang $(35,9 \%)$. Hasil penelitian ini sejalan dengan penelitian yang dilakukan Siagian $^{6}$ bahwa responden laki-laki lebih banyak menyirih dibanding responden perempuan, sedangkan penelitian Warongan et al. $^{3}$ hanya terbatas pada responden perempuan saja. Berdasarkan hasil wawancara diperoleh dari responden lakilaki bahwa kebiasaan menyirih baik dilakukan karena dapat memperkuat gigi, menghilangkan bau mulut dan dapat menghilangkan sakit gigi. Selain itu kebiasaan menyirih juga dapat dilakukan sebagai aktifitas diwaktu senggang. Hal ini juga bisa terjadi dengan adanya perbedaan tradisi dan kebudayaan, karena kebiasaan menyirih memiliki satu nilai persaudaraan yang sangat kuat dengan rasa sosialitas yang tinggi dan tidak dapat digantikan dengan benda jenis apapun. ${ }^{6,9,11}$

\section{Distribusi responden berdasarkan lama menyirih}

Lama menyirih diukur berdasarkan berapa lama responden melakukan kebiasaan menyirih, dihitung dari pertama kali responden menyirih (tahun). Hasil penelitian mendapatkan yang terbanyak ialah responden yang memiliki kebiasaan menyirih 5-10 tahun yaitu 19 orang $(48,7 \%)$ (Tabel 6). Hasil wawancara mendapatkan bahwa pada awalnya responden hanya ingin mencoba tetapi lama kelamaan menimbulkan rasa ketergantungan (ketagihan). Rasa ketagihan merupakan suatu alasan sebagian besar penyirih untuk meneruskan kebiasaan menyirih karena dalam biji pinang terdapat kandungan arekolin yang dapat menimbulkan rasa ketergantungan (ketagihan). Menyirih dianggap suatu kebiasaan yang penting dilakukan untuk mempertahankan gigi selagi gigi masih ada. Hal ini mungkin disebabkan karena responden merupakan masyarakat yang tergolong kelompok usia menengah atau mungkin disebabkan oleh perbedaan distribusi usia kelompok yang diteliti. ${ }^{8.10}$

\section{Distribusi responden berdasarkan frekuensi menyirih perhari}

Hasil penelitian mendapatkan bahwa yang terbanyak ialah responden yang memiliki kebiasaan menyirih 3-5 kali 
sebanyak 24 responden $(61,5 \%)$ (Tabel 7). Berdasarkan hasil wawancara dengan responden bahwa kebiasaan menyirih sama halnya dengan merokok yang dapat menyebabkan ketergantungan dan terkadang bahan agak susah didapat, terutama kapur sehingga banyak responden yang melakukan kebiasaan menyirih 3-5 kali sehari untuk menghemat bahan agar persediaan masih tetap ada. ${ }^{12}$

\section{Analisis hubungan status gingiva dan lama menyirih}

Hasil penelitian dengan daftar pertanyaan atau kuesioner pada 39 responden (Tabel 8) menunjukkan bahwa pada responden yang memiliki kebiasaan menyirih $>10$ tahun yang terbanyak ialah memiliki status gingiva berat sebanyak 15 responden (38,5\%). Responden yang memiliki kebiasaan menyirih 5-10 tahun terbanyak dengan status gingiva sedang sebanyak 11 orang $(28,2 \%)$. Responden yang memiliki kebiasaan menyirih <5 tahun terbanyak memiliki status gingiva ringan sebanyak 3 responden (7,7\%). Analisis Chi-square memperoleh hasil dengan nilai $\mathrm{p}=0,000(\mathrm{p}<0,05)$ yang artinya terdapat hubungan bermakna antara lama menyirih dengan status gingival (Tabel 8). Berdasarkan hasil penelitian terdapat $38,5 \%$ kategori berat yang lama menyirihnya lebih dari 10 tahun; hal ini disebabkan karena semakin lama kebiasaan menyirih dilakukan maka semakin tinggi risiko seseorang untuk mengalami gingivitis. ${ }^{5.10}$ Penyebab terjadinya gingivitis disebabkan karena adanya kalkulus atau karang gigi akibat stagnasi saliva dan terdapat kalsium pada campuran bahan menyirih. Hal ini didukung dengan penelitian Siagian mengenai kebersihan gigi dan mulut penyirih di Manado yang menunjukan skor kalkulus penyirih yang cenderung tinggi. ${ }^{5.9}$

\section{Analisis hubungan status gingiva dan frekuensi menyirih perhari}

Hasil penelitian berdasarkan frekuensi menyirih perhari yang menggunakan kuesioner atau daftar pertanyaan pada 39 responden diperoleh hasil pada Tabel 6 . Berdasarkan analisis menggunakan Chisquare diperoleh hasil dengan nilai $p=0,001 \quad(p<0,05)$ yang artinya terdapat hubungan bermakna antara frekuensi menyirih dalam sehari dengan status gingiva.

Berdasarkan hasil penelitian terdapat $30,8 \%$ kategori berat yang frekuensi menyirihnya 3-5 kali dalam sehari. Hal ini dikarenakan semakin sering responden melakukan kebiasaan menyirih maka semakin banyak kontak antara jarigan mukosa mulut dengan bahan yang digunakan untuk menyirih, seperti kapur yang dapat meyebabkan bertumpuknya kalkuluskemudian ditambah dengan kebersihan mulut Oral Hygiene (OHI-S) yang tidak dijaga, diperparah dengan kebiasaan masyarakat yang sudah mengantikan kebiasaan menggosok gigi dengan kebiasaan menyusur atau menggosok segumpalan bahan meyirih maka akan semakin tinggi risiko untuk mengalami gingivitis. Jika kebiasaan menyirih tersebut dibiarkan dan dilakukan terus menerus berpeluang menyebabkan terjadinya kanker pada rongga mulut. Berdasarkan penelitian sebelumnya buah pinang dan daun sirih dapat memicu terjadinya kanker rongga mulut karena mengandung zat seperti arecoline dan tanin yang menyebabkan kerusakan DNA. $5,6,9,10,13,14$

\section{SIMPULAN}

Dari hasil penelitian pada masyarakat dengan kebiasaan menyirih di Kecamatan Manganitu didapatkan bahwa:

1. Status gingiva dari sebagian besar masyarakat tergolong kategori berat

2. Lama menyirih pada sebagian besar masyarakat terdapat pada 5-10 tahun sedangkan frekuensi menyirih pada sebagian besar masyarakat ialah $3 \quad-5$ kali

3. Terdapat hubungan bermakna antara lama menyirih dengan status gingiva $(\mathrm{p}=0,000)$

4. Terdapat hubungan bermakna antara frekuensi menyirih dengan status 
gingiva $(\mathrm{p}=0,001)$

sehingga dapat disimpulkan bahwa status gingiva masyarakat Kecamatan Manganitu yang memiliki kebiasaan menyirih tergolong dalam kategori berat

\section{SARAN}

1. Perlu dilakukan penyuluhan pada masyarakat yang memiliki kebiasaan menyirih agar memahami dampak dan bahaya dari kebiasaan menyirih.

2. Perlu dilakukan penelitian lebih lanjut mengenai pengaruh kebiasaan menyirih akan kesehatan rongga mulut agar bisa mengurangi tingkat keparahan kesehatan gigi dan mulut khususnya pada kesehatan gingiva untuk generasigenerasi berikutnya.

3. Perlu dilakukan penelitian lanjutan dengan menggunakan uji laboratorium terhadap kandungan dari bahan menyirih untuk mengetahui faktor paling dominan yang dapat menyebabkan terjadinya gingivitis.

\section{DAFTAR PUSTAKA}

1. Aditama AR. Hubungan pengetahuan tentang kebersihan gigi dengan status kebersihan gigi pada siswa SDN 5 Karang Anyar kabupaten Lampung Selatan. Jurnal STIKes Aisyah Pringsewu Lampung. 2013;2(22):2.

2. Tambunan EGR. Gambaran penyakit periodontal pada penderita diabetes melitus di rumah sakit umum pusat Prof. Dr. R. D. Kandou Manado. eGiGi. 2015;3(1):535.

3. Warongan G. Gambaran status gingiva pada ibu hamil di puskesmas Bahu Manado. Jurnal. eGiGi. 2015;3(1):2-3.

4. Waluyono HBT. Analisis faktor-faktor yang berhubungan dengan kejadian gingivitis pada ibu hamil di wilayah kerja puskesmas Talang Tegal. Jurnal Poltekes Kemenkes Semarang. 2011;3(7):170-1.

5. Tandiarang, GW. Pengaruh lama dan frekuensi menyirih dangan terjadinya gingivitis pada masyarakat di Kabupaten Toraja Utara [Skripsi].
Makassar: Universitas Hasanuddin; 2015.

6. Siagian VK. Status kebersihan gigi dan mulut suku papua pengunyah pinang di Manado. Dentofasial. 2012;11(1):16.

7. Flora MS, Mascle-Taylor CGN, Rahman M. Betel quid chewing and its risk factors in Bangladeshi adults. WHO South-East-Asia Journal of Public Health 2012. 1(2).h. 169-181.

8. Dame RM, Vonny NSW, Supit A. Journal. Gambaran kebiasaan menyirih dan lesi mukosa mulut pada mahasiswa Papua di Manado. E-Gigi J Ilm kedokteran Gigi. 2012. 1(2).h. 1-3.

9. Fatlolona WO, Pandelaki K, Mintjelungan CN. Hubungan status kesehatan periodontal dengan kebiasaan menyirih pada mahasiswa etnis Papua di Manado. e-GiGi. 2013;1(2):1-4.

10. Arini NW. Hubungan menyirih dengan keadaan jaringan periodontal pada orang yang menyirih di Banjar Sedana Merttha Kota Denpasar. Jurnal Kesehatan Gigi. 2013;1(2):76-80.

11. Kadek NWP. Hubungan kebiasaan menyirih terhadap kejadian karies pada gigi pada lanjut usia di desa batubulan kangin. Journal Virgi. 2015;1:200-208.

12. Iptika A. Keterkaitan kebiasaan dan kepercayaan mengunyah sirih pinang dengan kesehatan gigi. Available from: journal.unair.ac.id/ downloadfullpapers-aun712fc6fc 38full.pdf.p. 64-9.

13. Ridzuan NZB. Kanker rongga mulut disebabkan oleh kebiasaan menyirih (laporan kasus). Available from: URL: http:

//repository.usu.ac.id/handle/1234

56789/7897Skripsi.2009. p. 21-30, 3640.

14. Sama R. Kebiasaan mengunyah sirih dan hubungan dengan indeks penyakit periodontal pada wanita di Kecamatan Lau Belang Kabupaten Karo. Available from: http://www. repository.usu.ac.id/handle/123456789 /8032. 2003. p. 46-48. 